\title{
Effect of pasture species on internal parasites of lambs
}

\author{
T.L. KNIGHT', R.A. MOSS', T.J. FRASER', J.S. ROWARTH ${ }^{1,3}$ and R.N. BURTON ${ }^{2}$ \\ ${ }^{1}$ AgResearch, PO Box 60, Lincoln, Canterbury \\ ${ }^{2}$ AgResearch, Winchmore Research Station, Private Bag 803, Ashburton \\ ${ }^{3}$ Plant Science Department, PO Box 84, Lincoln University, Canterbury
}

\section{Abstract}

Increasing resistance of gastro-intestinal nematode parasites to anthelmintics and consumer resistance to the possibility of residues in animal products have prompted research on the effect of pasture species on nematodes and animal performance. Lambs (either infected with high rates of gastrointestinal nematodes or maintained nematode-free) were grazed on pure swards of chicory, high- or low-endophyte ryegrass, cocksfoot, tall fescue, lucerne, lotus, white clover or plantain. Infected lambs that grazed chicory had lower faecal egg counts and adult nematode populations, and higher carcass weights, than lambs grazed on plantain or the grass species; lambs that grazed legumes generally had intermediate counts, populations and weights. When kept parasite-free, carcass weights were up to $48 \%$ greater than in the nematodeinfected treatments. On farmlets run over 3 years, substituting $30 \%$ of the ryegrass area with lucerne or replacing the ryegrass with a multi-species mix consisting predominantly of bromes, tall fescue, phalaris, timothy and red and white clover, had no effect on gastro-intestinal nematode larvae, lamb f faecal worm egg or adult nematode numbers. It is concluded that a diet of pure chicory affects internal parasite populations but the small proportion included in the farmlet studies had no effect.

Keywords: Cichorium intybus, Dactylis glomerata, Festuca arundinacea, gastro-intestinal nematodes, lambs, Lolium perenne, Lotus corniculatus, Medicago sativa, pasture species, Plantago lanceolata, Trifolium repens

\section{Introduction}

Anthelmintic drenches have traditionally been used to control gastro-intestinal nematodes in sheep and cattle, thus reducing the detrimental effects of the parasites on livestock performance. However, anthelmintics are becoming increasingly ineffective owing to an increase in nematode resistance (Bailey 1991). Furthermore, there is consumer resistance to anthelmintic-sourced residues in meat and contamination in the environment (Wall \&
Strong 1987). Increasing emphasis is thus being placed on non-chemical methods of nematode control.

Pasture species have been shown to influence nematode larval population dynamics (Knapp 1964; Silangwa \& Todd 1964; Moss \& Vlasoff 1993); in particular, lucerne (Medicago sativa) and chicory (Cichorium intybus) have been shown to support lower nematode populations in sheep than pure grass swards (Scales et al. 1994). Growth rates of lambs dosed with parasitic larvae are higher on lotus (Lotus pedunculatus) than other pasture species (Niezenet al. 1994). Plantain (Plantago lanceolata) is also reputed to have an anthelmintic effect (Grieve 1931), but recent research has produced no positive result (Robertsonet at. 1-995).

The two projects reported here were established to assess the effect of different pasture species and mixtures on gastro-intestinal nematode populations and lamb performance.

\section{$M$ aterials and methods}

\section{Project 1}

This project was conducted over three years (1993 to 1995) as three separate experiments containing different ranges_of_species_(Table-1-)-but-with-similar-designs: Each species area was divided into "infected" and "control" treatments and male Coopworth lambs restrictively randomised on the basis of liveweight; lambs remained on these forage treatments for the duration of the trial (Table 1). In October 1991 the forages for the 1993 trial were established on 20 ha at the Templeton Research Station near Christchurch. The 1994 experiment was also established at Templeton Research Station on a new cultivated area. Experiment 3 had been established in 1992, at the AgResearch farm at Lincoln, for-a-pasture- ${ }^{-}$species comparison, and $^{-}$in December 1994 each species plot was divided into the two parasite treatments. All forage areas were either cultivated and sown down with no grazing before the trial began or were not grazed for 7 months before trial commencement to reduce larval carry-over. Excess herbage growth before the trials began was removed as hay or silage. The lambs were offered approximately $3 \mathrm{~kg}$ dry matter/ head/day and rotationally grazed with weekly shifts using four or five breaks. The infected Iambs were orally dosed with third-stage $\left(\mathrm{L}_{3}\right)$ larvae (Table 1$)$ and the 
control lambs were drenched with the anthelmintic Ivomec ${ }^{\text {TM }}$ at fortnightly intervals. All lambs received $3 \mathrm{mg}$ of selenium monthly. Irrigation and fertiliser were applied to all treatments to ensure optimum pasture growth rates.

Ten fresh faecal samples were recovered, from the ground in 1993 and from the rectum in the final two years, for faecal egg count (FEC) analysis every fortnight at the time of shifting the lambs to a new break. At slaughter, hot carcass weight was recorded from all lambs, and the abomasum and $6 \mathrm{~m}$ of small intestine recovered from five lambs per infected treatment for adult nematode count.

The data were analysed by analysis of variance. Since the experiments consisted of only one duplicate each year, the variation from animal to animal was used to assess the error term; the analysis for FEC and adult nematode populations used square root transformed data.

\section{Project 2}

Three 2 ha farmlets were established at the Winchmore Research Station, Mid-Canterbury, on a Lismore stony silt loam. These were sown after 5 months' cultivation, with either $100 \%$ of the area in ryegrass (Lolium perenne cv. Embassy) and white clover (Trifolium repens. $c v$. Grasslands Huia), or $70 \%$ ryegrass-white clover (as above) with $30 \%$ in lucerne (Medicago sativa cv. Grasslands Otaio), or $70 \%$ in a multi-species mix (MS) consisting of tall fescue (Festuca arundinacea, cv. AU Triumph), grazing brome (Bromus stamineus cv. Grasslands Gala), prairie grass (Bromus unioloides cv. Grasslands Matua), phalaris (Phalaris aquatica cv. Grasslands Maru), timothy (Phleum pratense $c v$. Grasslands Kahu), Huia white clover, red clover (Trifolium pratense cv. Grasslands Pawera), plantain (Plantago fanceolata cv. Grasslands Lancelot), chicory (Cichorium intybus cv. Grasslands Puna) and yarrow (Achillea millefolium), and 30\% in Otaio lucerne.

\section{Management}

Farmlets were stocked with Coopworth ewes at $15 /$ ha which were mated to Coopworths. All systems were continuously rotationally grazed with identical rotation lengths and identical minimum feed allowances during winter. Lamb numbers were adjusted to a common ratio of 1.3 /ewe. They were weaned at 11 weeks then grazed immediately ahead of their dams. A representative sample of $60 \%$ of the lambs was slaughtered from each system during late summer and the remainder during May. Ewes received an anthelmintic immediately before treatment allocation while lambs received an anthelmintic once annually during summer. All pastures were irrigated and received a common fertiliser input. The experiment ran for 3 years, with measurements taken over the last two.

\section{Measurements}

Numbers of gastro-intestinal nematode larvae and pasture botanical composition were assessed monthly, FEC were made at 3-weekly intervals from lambs and adult nematodes assessed from equal numbers of lambs at slaughter. Analysis of variance was used to test differences using years as the error term. All LSD values are at the 0.05 level of significance.

\section{Results}

Project 1

\section{Faecal egg count}

In 1993, infected lambs that grazed lucerne had a significantly $(P<0.05)$ lower FEC than infected lambs that grazed chicory, which were significantly $(\mathrm{P}<0.05)$ lower than for lambs that grazed the grasses (Table 2). In 1994, lambs that grazed chicory, white clover or plantain had lower $(\mathbf{P}<0.05)$ FEC than lambs that grazed low-endophyte (LE) ryegrass. In 1995 lambs that grazed lotus had higher $(P<0.05)$ FEC than lambs that grazed chicory, high-endophyte (HE) ryegrass, white clover or plantain, which did not differ.

\section{Gastro-intestinal nematodes}

In 1993 (Table 3), nematodes in infected lambs that grazed chicory and luceme were significantly $(\mathrm{P}<0.05)$ lower than those on the grass treatments. In 1994 lambs that grazed chicory produced lower $(\mathbf{P}<0.05)$ counts than lambs grazed on LE ryegrass, white clover or 
Table 2 Effect of herbage species on square-root-transformed mean faecal egg counts from infected lambs over the duration of the experiments (Project 1).

\begin{tabular}{lccr}
\hline & 1993 & 1994 & 1994195 \\
\hline Chicory & 24.3 & 38.3 & 35.3 \\
Ryegrass HE & & 47.4 & 27.6 \\
Ryegrass LE & 27.9 & & \\
Cocksfoot & 30.3 & & \\
Tall fescue & 27.2 & & \\
Lucerne & 21.3 & 37.0 & 50.7 \\
Lotus clover & & 40.5 & 31.7 \\
White & & 4.3 & 13.0 \\
Plantain & & & \\
LSD (5\%) & 2.7 & &
\end{tabular}

Table 3 Effect of herbage species on square-root-transformed adult gastro-intestinal nematode burdens from infected lambs at slaughter (Project I).

\begin{tabular}{lccc}
\hline & 1993 & 1994 & 1995 \\
\hline $\begin{array}{l}\text { Chicory } \\
\text { Ryegrass HE }\end{array}$ & 116.5 & 127.5 & 163.4 \\
Ryegrass LE & 301.3 & 227.7 & 230.7 \\
Cocksfoot & 182.6 & & \\
Tall fescue & 216.0 & & \\
Lucerne & 108.5 & & \\
Lotus & & 183.2 & 176.4 \\
White clover & & 223.9 & 294.8 \\
Plantain & 51.8 & 46.5 & 53.7 \\
LSD (5\%) & & & \\
\hline
\end{tabular}

Table 4 Effect of herbage species on hot carcass weight $(\mathrm{kg})$ of infected and control lambs and \% carcass weight increase of infected vs control lambs (Project 1 ).

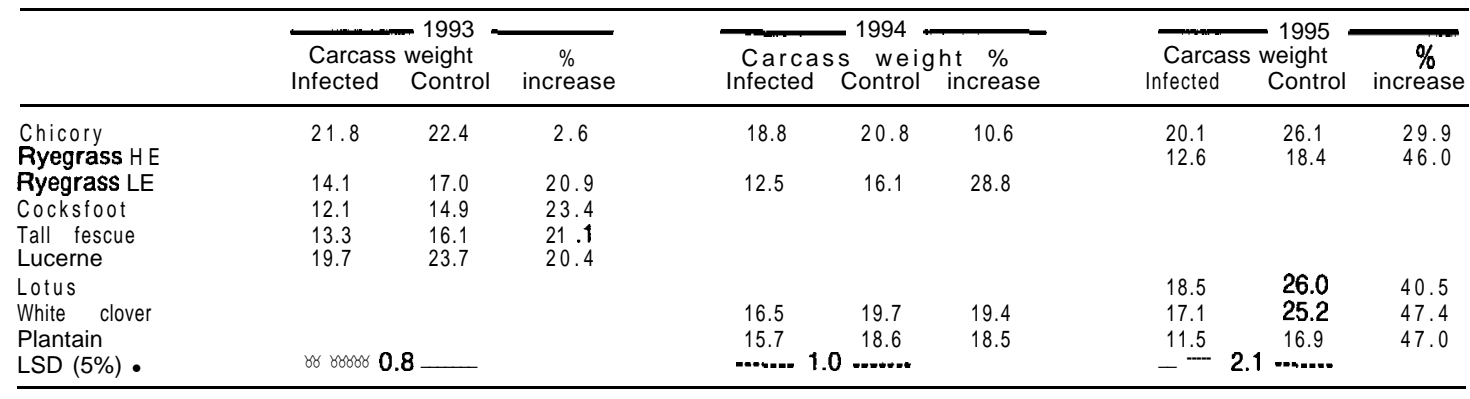

- the LSD applies to the carcass weights only

plantain, and in 1995, lambs that grazed chicory, lotus and white clover had similar populations and were significantly $(\mathrm{P}<0.05)$ lower than lambs grazed on $\mathrm{HE}^{-}$ ryegrass, which were significantly $(\mathrm{P}<0.05)$ lower than lambs grazed on plantain.

\section{Carcass weighf}

In 1993, the carcass weights (Table 4) from luceme fed lambs were similar to those grazed on chicory but the \% increase (Table 4), which is the calculated difference between the carcass weights of the infected and control lambs expressed as a percentage of the infected treatment, of these lambs grazed on lucerne was similar to that produced from the lambs grazed on the grass treatments. The $\%$ increase in the lambs grazed on chicory was substantially lower than the other forages.

In the final two years chicory continued to produce the highest carcass weights and lowest \% increases, followed by the legumes. Plantain was superior to the LE ryegrass in 1994 and similar to the HE ryegrass in 1995 .

Project 2

The ryegrass-based swards consisted of ryegrass $(91 \%)$, other grasses $(2 \%)$, legumes $(5 \%)$ and weeds $(2 \%)$.
The MS swards contained fescue $(27 \%)$, bromes $(24 \%)$, phalaris and timothy (17\%), other grasses (9\%), red clover and white clover $(11 \%)$, and chicory $(4 \%)$, while the contribution of plantain, yarrow and weeds was small (<3\% each). Lucerne swards comprised luceme $(71 \%)$, grass $(19 \%)$, weeds $(6 \%)$ and clover $(4 \%)$.

\section{Gastro-intestinal nematodes}

Including luceme in a ryegrass system had no effect on larval populations, FEC in lambs, or the number of adult nematodes in lambs (Table 5). Substituting ryegrass with MS while retaining lucerne had no effect on pasture larval numbers, FEC counts or adult nematode populations in lambs (Table 5).

Table 5 Effect of herbage species on gastro-intestinal nematode populations (square root transformed) (Project 2).

\begin{tabular}{lccc}
\hline Pasture species & Larvae' & $\begin{array}{c}\boldsymbol{\theta . p . g . ~} \\
\text { Lambs }\end{array}$ & $\begin{array}{c}\text { Adults } \\
\text { Lambs }\end{array}$ \\
\hline Ryegrass & $73.5 \mathrm{a}$ & $\mathbf{2 4 . 0 2 a}$ & $\mathbf{1 5 6 . 3 \mathrm { a }}$ \\
Ryegrass + lucerne & $83.5 \mathrm{a}$ & $\mathbf{2 4 . 6 7 a}$ & $\mathbf{1 6 8 . 5 \mathrm { a }}$ \\
MS + lucerne & $71.5 \mathrm{a}$ & $\mathbf{2 1 . 8 6 a}$ & $161.1 \mathrm{a}$ \\
LSD & 27.5 & 8.53 & 42.6 \\
\hline
\end{tabular}

1 larvae/kg pasture dry matter 


\section{Discussion}

\section{Project I}

Grazing lambs, which had been infected with parasite larvae, on chicory produced FEC and adult nematode numbers as low as or lower, and carcass weights that, except for lotus in the final year, were significantly ( $P>0.05)$ heavier than for lambs on the other species in these trials. Also the percentage increase in carcass weight from chicory-grazed lambs was substantially lower each year compared with the other species. The rotation length of 4-5 weeks used in these experiments was probably conducive to maximum larval challenge in the lambs, and the large production losses will reflect this. As chicory does not contain any known anthelmintic properties, these superior results are probably caused by higher quality forage. The legume species were generally superior to the grasses and plantain. Plantain, which has been reported to reduce parasite populations (Grieve 1931), and Lotus corniculatus, with its reported tannin content (Waghorn et al.1987), did not reduce parasite populations in this project. This supports the findings of Robertson et al. (1995).

\section{Project 2}

Lucerne was included in the farmlet systems, as it has been associated with improved nutrition (Nicol \& McLean 1970), which could reduce parasitism of lambs (Steel et al. 1984). Furthermore, Moss \& Vlassoff (1993) and Scales et al. (1994) recovered fewer larvae from luceme swards compared with those based on commonly used grass pastures. Moss \& Vlassoff (1993) attributed this to a micro-climate in the lucerne sward less conducive to nematode development and survival than that of ryegrassor prairie grass-based swards. Despite these prospects and the relatively high number of larvae on pasture ( $>100000 / \mathrm{kg}$ DM in May 1994), changing the pasture species within farmlet systems failed to affect larval numbers or populations in lambs. Chicory, which was included in the MS pastures in the farmlet systems, has been shown to support fewer larvae (Moss \& Vlassoff 1993; Scales et al. 1994) than grass-based swards. However, the quantity of chicory in the present experiment declined from $6 \%$ to $2 \%$ of the dry matter produced in summer and autumn during years 1 and 2 respectively, and was probably too low to be of consequence.

More work is required to investigate the reason for the positive effect of grazing chicory in Project 1 and to find management systems to exploit this effect.

\section{ACKOWLEDGEMENTS}

We wish to thank MRDC for funding Project 1 and AGMARDT for funding Project 2. We also thank the field service staff at Winchmore, Templeton and Lincoln for field assistance and Dave Saville for the statistical analysis.

\section{REFERENCES}

Bailey, K.M.1991. Anthelmintic ineffectiveness in New Zealand 1989-1990. Surveillance (4): 38-39.

Grieve, M. 1931. A modern Herbal. 912p. Great Britain: Jonathan Cape Ltd.

Knapp, S.E. 1964. Relationship of different species of forage to the survival and infectivity of Haemonchus Contortus in lambs. The journal of parasitology 50 (1): $144-148$.

Moss, R.A.; Vlassoff, A. 1993. Effect of herbage species on gastrointestinal roundworm populations and their distribution. New Zealand journal of agricultural research 36: 371-375.

Nicol, A.M.; McLean, J.W. 1970. The influence of pasture species and exogenous oestrogen treatment on the liveweight gain and carcass composition of lambs. New Zealand journal of agricultural research 13: 385-394.

Niezen, J.H.; Waghorn, T.S.; Raufaut, K.; Robertson, H.A.: McFarlane, R.G. 1994. Lamb weight gain and faecal egg count when grazing one of seven herbages and dosed with larvae for six weeks. Proceeding of the New Zealand Society of Animal Production $54: 15-18$.

Robertson, H.A.; Niezen, J.H.; Waghorn, G.C.; Charleston, W.A.G.; Jinlong, M. 1995. The effect of six herbages on liveweight gain, wool growth and faecal egg count of parasitised ewe lambs. Proceedings of the New Zealand Society of Animal Production 55: 199-201.

Scales, G.H.; Knight, T.L.; Saville, D.J. 1994. Effect of herbage and feeding level on internal parasites and production performance of grazing lambs. New Zealand journal of agricultural research 38: 237 247.

Silangwa, S.M.; Todd, A.C. 1964. Vertical migration of Trichostrongylid larvae on grasses. Journal of parasitology 50 (2): 278-285.

Steel, J.W.: Wagland, B.M.; Dineen, J.K. 1984. Effect of plane of nutrition on development of resistance to Trichostrongylus colubriformis in weaner lambs. Abstracts of the joint conference of New Zealand Society for Parasitology and Australian Society for Parasitology, Christchurch, New Zealand. 27-30.

Waghorn, G.C.; John, A.; Jones, W.T.; Shelton, I.D. 1987. Nutritive value of Lotus corniculatus L. containing low and medium concentrations of condensed tannins for sheep. Proceedings of the New Zealand Society of Animal Production 47: 25-30.

Wall, R.; Strong, 1. 1987. Environmental consequences of treating cattle with the antiparasitic drug Ivermectin. Nature 327: 418 . 